\title{
Pengaruh RGEC (Risk Profile, Good Corporate Governance Earning, Capital) terhadap Financel Distress
}

\author{
Fikri Hakim Ermar ${ }^{1 *}$, Suhono $^{2}$ \\ Universitas Singaperbangsa Karawang, Indonesia \\ 1610631030114@student.unsika.ac.id, suhono@fe.unsika.ac.id
}

*Corresponding Author

Submitted: August, 29, 2020

Accepted: October, 17, 2020

Published: February, 1, 2021

\begin{abstract}
This study aims to determine the effect of RGEC (Risk Profile, Good Corporate Governance, Earnings and Capital) on Financial Distress in banks listed on The Indonesia Stock Exchange (IDX) for the period of 2016-2019. The sample data used is the result of the purposive sampling technique and the samples declared worthy to be utilized are 21 banks. During the study conducted, the method was adopted which is a method of logistic regression analysis using SPSS 25 program aid. The results of the research show that the variables that are known can affect the Financial Distress is Return On Asset affect negatively and significantly. Meanwhile, variabels that do not affect Financial Distress are Non Performing Loan (NPL), Loan to Deposit Ratio, Good Corporate Governance, and Capital Adequacy Ratio. Simultaneously Non Performing Loans, Loan to Deposit Ratio, Good Corporate Governance, Return on Assets and Capital Adequacy Ratio have a significant effect on Financial Distress.
\end{abstract}

Keyword : NPL, LDR, GCG, ROA, CAR, Financial Distress

\section{PENDAHULUAN}

Kinerja keuangan sehat atau tidaknya suatu bank dapat diukur melalui laporan keuangan yang diterbitkan bank di BEI atau di situs masing-masing perbankan yang berisi informasi mengenai posisi keuangan perusahaan, kinerja serta perubahan posisi keuangan perusahaan, yang sangat berguna untuk mendukung pengambilan keputusan yang tepat seperti yang tertuang dalam Peraturan Bank Indonesia (PBI) No.13/1/PBI/2011 tanggal 5 Januari 2011 menggantikan PBI sebelumnya Nomor 6/10/PBI/2004 tentang sistem penilaian tingkat kesehatan bank umum yang telah berlaku selama hampir 7 tahun.

Namun setelah terjadinya krisis ekonomi, banyak sekali fenomena bank yang mengalami kondisi financial distress atau kesulitan keuangan hingga melakukan merger bahkan ada yang sampai dilikuidasi oleh pemerintah. Dalam kasus perbankan yang paling banyak mengalami kerugian akhir-akhir ini terjadi pada PT Bank Permata Tbk (BNLI) pada tahun 2016 mencatat rugi bersih sebesar Rp 6,48 triliun, padahal ditahun 2015 Bank Permata laba bersih sebesar Rp 247,1 miliar. Berdasarkan laporan keuangan konsolidasi Bank Permata yang diserahkan pada Bursa Efek Indonesia, tercatat kerugian ini disebabkan karena adanya pencadangan terhadap kredit bermasalah tahun 2016 sebesar Rp 12,2 triliun atau naik tiga kali lipat dari tahun 2015 yang sebesar Rp 3,6 triliun. Sehingga Bank Permata akan mengalami kesulitan keuangan karena harus menutupi kredit bermasalah yang tinggi, otomatis pemasukan yang diterima oleh Bank Permata pun turun drastis. (Kontan,2017).

Financial distress terjadi sebelum perusahaan menghadapi kegagalan ataupun kebangkrutan. Kondisi financial distress merupakan kondisi keuangan dimana keuangan perusahaan dalam keadaan tidak sehat atau krisis (Ruslinawati, 2017). Financial Distress pada penelitian ini menggunakan model Altman Z-score modifikasi non perusahaan manufaktur untuk mengetahui 
kondisi keuangan perbankan. Berikut ini disajikan tabel perbankan yang mengalami kondisi financial distress antara periode 2016-2019:

Tabel 1. Tingkat Kesulitan Keuangan (Financial Distress) Perbankan periode 2016-2019

\begin{tabular}{|l|c|c|c|c|}
\hline \multirow{2}{*}{ Nama Perbankan } & \multicolumn{4}{c|}{ Altman Z-score modifikasi } \\
\cline { 2 - 5 } & 2016 & 2017 & 2018 & 2019 \\
\hline Bank Harda Internasional Tbk & 0,963 & 0,866 & 0,278 & 0,238 \\
\hline Bank Bukopin Tbk & 0,794 & 0,335 & 0,406 & 0,181 \\
\hline Bank MNC Internasional Tbk & 0,865 & $-0,280$ & 0,393 & 0,202 \\
\hline Bank Jtrust Indonesia Tbk & $-1,958$ & $-1,409$ & $-1,600$ & $-1,250$ \\
\hline Bank QNB Indonesia Tbk & 0,416 & 0,382 & 0,999 & 0,855 \\
\hline Bank Permata Tbk & 0,173 & 0,855 & 0,928 & 1,087 \\
\hline
\end{tabular}

Sumber : www.idx.co.id (Data diolah)

Berdasarkan tabel 1 menunjukkan bahwa nilai $z$-score perbankan tersebut selama periode 2016-2019 dalam kriteria yang tidak sehat yaitu $<1,1$, kondisi perbankan yang tidak sehat pada periode tersebut akan berdampak terhadap kemungkinan terjadinya kebangkrutan di masa yang akan datang. Hal tersebut tentu menjadi sebuah permasalahan yang harus segera ditangani oleh sebuah lembaga perbankan yang keberadaan dan perannya crucial bagi stabilitas roda perekonomian sebuah negara.

Industri perbankan dalam kegiatan usahanya sangat mengandalkan kepercayaan masyarakat sehingga tingkat kesehatannya perlu dipelihara. Pemeliharaan kesehatan bank dilakukan untuk menghadapi risiko-risiko perbankan menggunakan penilaian kinerja bank dengan RGEC yaitu: Risk profile, Good corporate governance, Earnings, Capital.

Risk profile dalam penelitian ini menggunakan proxy Non Performing Loan (NPL) dan Loan to Deposit Ratio (LDR). Non Performing Loan (NPL) merupakan kredit yang menunggak melebihi batas waktu dan terdiri dari 3 bagian yaitu kurang lancer, diragukan, dan macet (Ismail, 2014:224). Loan to Deposit Ratio (LDR) menurut Riyadi (2015:199) adalah perbandingan total kredit terhadap Dana Pihak Ketiga (DPK) yang dihimpun oleh bank.

Menurut Hamdani (2016:1) lemahnya Corporate Governance atau Tata kelola menjadi salah satu penyebab terjadinya krisis ekonomi di Indonesia. Terkait dengan mekanisme Corporate Governance sendiri, peneliti akan menguji menggunakan proxy Nilai Komposit.

Earning dalam penelitian ini menggunakan proxy Return on Asset (ROA). Salah satu indikator penting dalam mencapai kinerja suatu perusahaan yang optimal adalah laba. Rasio ini memberikan gambaran tentang tingkat efektivitas pengelolaan perusahaan. Menurut Riyadi (2011) ROA adalah rasio profitabiltas yang menunjukkan perbandingan antara laba sebelum pajak dengan total aset bank.

Capital dalam penelitian ini menggunakan proxy Capital Adequacy Ratio (CAR). Menurut Kasmir (2014:46) CAR adalah perbandingan rasio tersebut antara rasio modal terhadap aktiva tertimbang menurut resiko dan sesuai ketentuan pemerintah.

Penelitian berikut berkaitan dan dapat digunakan sebagai penguat kondisi atau tulisan ini yaitu, Pradana (2016) menemukan bahwa Rasio Non performing Loan (NPL) berpengaruh signifikan terhadap financial distress, Sementara melalui penelitian yang dilakukan oleh Theodorus dan Artini (2018) Non Performing Loan ( NPL) tidak signifikan terhadap financial distress, Hasil yang serupa juga ditemukan oleh Zahronyana dan Mahardika (2018). Selanjutnya penelitian yang dilakukan oleh Khadapi (2017) Loan to Deposit Ratio (LDR) berpengaruh positif dan signifikan terhadap financial distress, Sementara hasil yang ditemukan oleh Sofiasani dan Gautama (2016) menyatakan Loan to deposit Ratio tidak berpengaruh terhadap financial distress. Penelitian yang dilakukan oleh Rustandi (2019) Good Corporate Govenance (GCG) berpengaruh negatif signifikan terhadap financial distress, Sementara hasil yang ditemukan oleh Sadida (2018) menyatakan Good Corporate Governance tidak berpengaruh terhadap financial distress. Penelitian yang dilakukan oleh Sofiasani dan Gautama (2016) menyatakan Return on Assets (ROA) tidak berpengaruh terhadap financial distress, Sementara variabel ROA pada penelitian Andari dan Wiksuana (2017) 
berpengaruh negatif signifikan terhadap Financial Distress. Penelitian yang dilakukan oleh Sajuri (2018) Capital Adequacy Ratio (CAR) berpengaruh terhadap financial distress, Sementara hasil yang ditemukan oleh Wijaya, Wahjoe dan Kurnia (2018) menyatakan Capital Adequacy Ratio tidak berpengaruh terhadap financial distress.

\section{Signalling Theory}

\section{KAJIAN PUSTAKA}

Menurut Suwardjono (2013:583) Signalling theory (teori pensignalan) merupakan manajemen yang selalu berusaha untuk mengungkapkan informasi privat yang menurut pertimbangannya sangat diminati oleh investor dan pemegang saham khususnya kalau informasi tersebut merupakan berita baik ( good news), manajemen juga berminat menyampaikan informasi yang dapat meningkatkan kredibilitasnya dan kesuksesan perusahaan meskipun perusahaan tersebut tidak diwajibkan.

Septiwardani (2018) Teori sinyal dalam topik financial distress menjelaskan bahwa jika kondisi keuangan dan prospek perusahaan baik, manajer member sinyal dengan menyelenggarakan akuntansi liberal. Sebaliknya, jika perusahaan dalam kondisi financial distress dan mempunyai prospek yang buruk, manajer memberi sinyal dengan menyelenggarakan akuntansi konservatif. Oleh karena itu manajemen perusahaan harus dapat menampilkan kondisi yang sebenarnya dari perusahaan, agar pihak eksternal atau investor dapat membuat keputusan dalam menyelesaikan masalah khususnya masalah kesulitan keuangan (financial distress) yang timbul disuatu perusahaan. Dan kebangkrutan dapat terhindarkan.

\section{Agency Theory}

Teori keagenan (agency theory) dibangun sebagai upaya untuk memahami dan memecahkan masalah yang muncul jika ada ketidak lengkapan kontrak informasi pada saat melakukan kontrak. Kontrak yang dimaksud adalah kontrak antara principal dan agent. Didalam teori agency yang dinyatakan oleh Jensen dan Mackling dalam Prabowo dan Purwanto (2015) bahwa teori keagenan membuat membuat suatu model kontraktual antara dua atau lebih orang (pihak), dimana salah satu pihak disebut agen dan pihak lain disebut prinsipal.

Menurut Scott (2012:359) teori keagenan adalah teori yang menggambarkan hubungan keagenan yang berasal dari hubungan adanya kontrak dimana satu atau lebih pemegang saham (principal) melibatkan manajemen (agent) untuk melakukan beberapa jasa atas nama mereka. Manajemen adalah pihak yang dikontrak oleh pemegang saham untuk bekerja demi kepentingan pemegang saham dan pihak manajemen akan selalu bertindak yang terbaik bagi kepentingan pemegang saham. Oleh karena itu, pihak manajemen harus bertanggung jawab kepada pemegang saham.

\section{Non Performing Loan}

Menurut Kasmir (2013 : 155) Non Performing Loan adalah Kredit bermasalah atat kredit yang didalamnya terdapat hambatan yang disebabkan oleh 2 unsur yakni dari pihak perbankan dalam menganalisis maupun dari pihak nasabah yang dengan sengaja atau tidak sengaja dalam kewajibannya tidak melakukan pembayaran. Semakin tinggi Non Performing Loan, maka akan semakin buruk kualitas kredit bank. Hal tersebut menyebabkan jumlah kredit bermasalah bank semakin meningkat sehingga kemungkinan bank mengalami financial distress semakin besar.

Rasio ini dirumuskan sebagai berikut (Surat Edaran Bank Indonesia Nomor 13/24/DPNP/2011) :

$$
\text { Non Performing Loan }=\frac{\text { Kredit Bermasalah }}{\text { Total Kredit }} \times 100 \%
$$

\section{Loan to Deposit Ratio}

Menurut Riyadi (2015:199) Loan to Deposit Ratio (LDR) adalah perbandingan total kredit terhadap Dana Pihak Ketiga (DPK) yang dihimpun oleh bank. Loan to Deposit Ratio menyatakan seberapa jauh kemampuan bank dalam membayar kembali penarikan dana yang dilakukan deposan 
dengan mengandalkan kredit yang diberikan sebagai sumber likuiditas. Dengan kata lain, seberapa jauh pemberian kredit kepada nasabah kredit dapat mengimbangi kewajiban bank untuk segera memenuhi permintaan deposan yang ingin menarik kembali uangnya yang telah digunakan oleh bank untuk memberikan kredit. Semakin tinggi rasio tersebut memberikan indikasi semakin rendahnya kemampuan likuiditas bank yang bersangkutan.

Loan to Deposit Ratio dapat di rumuskan sebagai berikut (Surat Edaran Bank Indonesia Nomor 13/24/DPNP/2011) :

$$
\text { Loan to Deposit Ratio }=\frac{\text { Jumlah Kredit Pihak Ketiga }}{\text { Total Dana Pihak Ketiga }} \times 100 \%
$$

\section{Good Corporate Governance}

Menurut Hamdani (2016:1) lemahnya Corporate Governance atau Tata kelola menjadi salah satu penyebab terjadinya krisis ekonomi di Indonesia. Penilaian faktor Good Corporate Governance merupakan penialian terhadap kualitas manajemen bank atas prinsip-prinsip Good Corporate Governance, prinsip ini berpedoman pada ketentuan Bank Indonesia mengenai pelaksanaan Good Corporate Governance bagi bank umum dengan memperhatikan karakteristik usaha bank.

Good Corporate Governance dapat di kategorikan sebagai berikut (Surat Edaran Bank Indonesia Nomor 13/24/DPNP/2011) :

1. Peringkat komposit 1 (PK-1), dengan nilai komposit $<1,5$ mencerminkan kondisi bank yang secara umum sangat sehat.

2. Peringkat komposit $2(\mathrm{PK}-2)$, dengan nilai komposit $1,5<$ komposit $<2,5$ mencerminkan kondisi bank yang secara umum sehat.

3. Peringkat komposit 3 (PK-3), dengan nilai komposit 2,5 < komposit $<3,5$ mencerminkan kondisi bank yang secara umum cukup sehat.

4. Peringkat komposit 4 (PK-4), dengan nilai komposit 3,5 < komposit $<4,5$ mencerminkan kondisi bank yang secara umum kurang sehat.

5. Peringkat komposit 5 (PK-5), dengan nilai komposit 4,5 < komposit $<5$ mencerminkan kondisi bank yang secata umum tidak sehat.

\section{Return on Assets}

Menurut Riyadi (2011:155-158) Return on Asset adalah rasio profitabiltas yang menunjukkan perbandingan antara laba sebelum pajak dengan total aset bank. Rasio ini digunakan untuk mengukur kemampuan manajemen bank dalam memperoleh keuntungan (laba) secara keseluruhan. Semakin besar Return on Asset suatu bank, semakin besar pula tingkat keuntungan yang dicapai bank tersebut dan semakin baik pula posisi bank tersebut dari segi penggunaan aset. Dengan demikian semakin tinggi aset bank dialokasikan pada pinjaman dan semakin rendah rasio permodalan, maka kemungkinan bank untuk gagal akan semakin meningkat.

Rasio ini dirumuskan sebagai berikut (Surat Edaran Bank Indonesia Nomor 13/24/DPNP/2011) :

$$
\text { Return on Asset }=\frac{\text { Laba Bersih Setelah Pajak }}{\text { Total Asset }} \times 100 \%
$$

\section{Capital Adequacy Ratio}

Menurut Kasmir (2014:46) Capital Adequacy Ratio adalah perbandingan rasio tersebut antara rasio modal terhadap aktiva tertimbang menurut resiko dan sesuai ketentuan pemerintah. Capital Adequacy Ratio adalah rasio yang memperhatikan seberapa jauh seluruh aktiva bank yang mengandung resiko (kredit, penyertaan, surat berharga, tagihan pada bank lain) ikut dibiayai dari 
dana modal sendiri bank disamping memperoleh dana-dana dari sumber-sumber di luar bank, seperti dana masyarakat, pinjaman, dan lain-lain :

Rasio ini dirumuskan sebagai berikut (Surat Edaran Bank Indonesia Nomor 13/24/DPNP/2011) :

$$
\text { Capital Adequacy Ratio }=\frac{\text { Jumlah Modal }}{\text { Jumlah Aktiva Menurut Risiko }(\text { ATMR })} \times 100 \%
$$

\section{Financial Distress}

Financial distress didefinisikan "telah kehilangan nilai pasar karena kinerja yang buruk, mereka adalah produsen yang tidak efisien, dan cenderung memiliki pengaruh finansial yang tinggi dan masalah cash flow. Dalam arti manajerial bahwa harga mereka cenderung lebih sensitif terhadap perubahan ekonomi, dan mereka cenderung untuk bertahan hidup di kondisi ekonomi yang memburuk (Bhattacharjee \& Han, 2014).

Dalam penelitian ini, Financial Distress diukur menggunakan model Altman Z-score. Zscore telah memodifikasi rumusnya untuk dapat digunakan oleh semua jenis perusahaan yang sebelumnya banyak digunakan disektor manufaktur. Seiring berjalannya waktu model Altman Zscore ini dapat digunakan di sektor jasa atau perbankan. Berikut persamaan Z-score dimodifikasi yaitu (Sagho dan Merkusiwati, 2015):

Keterangan :

$$
\mathrm{Z}=6,56 \mathrm{X} 1+3,26 \mathrm{X} 2+6,72 \mathrm{X} 3+1,05 \mathrm{X} 4
$$

$\mathrm{Z}=\mathrm{Z}$-score index

$\mathrm{X} 1=($ Working Capital $) /($ Total Asset $)$

$\mathrm{X} 2=($ Retained Earnings $) /($ Total Assets $)$

$\mathrm{X} 3=($ Earning before interest and taxes $) /($ Total Asset $)$

$\mathrm{X} 4=($ Market Value of Equity $) /($ Book value of total Liabilities $)$

Setelah menemukan Z-score index berdasarkan rumus yang ada diatas, kemudian dapat diklasifikasikan perbankan yang sehat dan bangkrut berdasarkan pada nilai Z-score model altman yaitu:

1. Nilai $Z<1,1$ maka perbankan masuk kategori Bangkrut.

2. Nilai $1,1<Z<2,60$ maka perbankan masuk dalam kategori Grey Area.

3. Nilai $Z>2,60$ maka perbankan masuk dalam kategori Aman.

Karena Variabel dependen dalam penelitian ini menggunakan skala pengukuran variabel dummy yang dibagi menjadi 2 kategori dan hanya menggunakan 2 angka seperti bilangan biner, jadi klasifikasi perbankan yang sehat dan bangkrut yaituseperti berikut :

1. "Non Financial Distress" dengan nilai Z-score $>1,1$ masuk kedalam kategori 0.

2. "Financial Distress" dengan nilai Z-score $<1,1$ masuk kedalam kategori 1.

\section{Hipotesis}

Berdasarkan landasan teori diatas, maka didapatkan hipotesis sebagai berikut :

H1 = NPL berpengaruh terhadap Financial Distress.

H2 = LDR berpengaruh terhadap Financial Distress.

H3 = GCG berpengaruh terhadap Financial Distress.

H4 = ROA berpengaruh terhadap Financial Distress.

H5 = CAR berpengaruh terhadap Financial Distress.

H6 = NPL, LDR, GCG, CAR dan ROA berpengaruh terhadap Financial Distress.

\section{METODE PENELITIAN}

Penelitian dilaksanakan dengan menggunakan data sekunder sebanyak 45 populasi perbankan yang tercatat di Bursa Efek Indonesia pada tahun 2016 hingga 2019 melalui situs www.idx.co.id. Sampel yang dimanfaatkan adalah sebanyak 21 perbankan dimana data tersebut 
telah memenuhi kriteria/syarat yang dibuat oleh peneliti. Sampel yang dipakai oleh peneliti dipilah dengan memakai metode purposive sampling dengan kriteria/syarat oleh peneliti. Adapun kriteria yang mendasari peneliti dalam pemilihan sampel penelitian adalah :

1. Perbankan yang terdaftar di Bursa Efek Indonesia secara berturut-turut selama periode pengamatan yaitu periode 2016 - 2019.

2. Perbankan yang terdaftar di Bursa Efek Indonesia secara berturut - turut menerbitkan Laporan Keuangan periode 2016 - 2019.

3. Perbankan yang terdaftar di Bursa Efek Indonesia secara berturut - turut menerbitkan Annual Report periode 2016 - 2019.

4. Perbankan yang menyajikan data perhitungan Rasio Keuangan (Non Performing Loan, Loan to Deposits Ratio, Good Corporate Covernance, Return on Assets dan Capital Adequacy Ratio) secara lengkap dan sesuai dengan Variabel yang akan diteliti selama pengamatan 2016-2019.

5. Perbankan yang mengalami kondisi financial distress selama periode 2016 - 2019 berturut turut serta yang tidak mengalami kondisi financial distress selama periode 2016 - 2019 berturut - turut.

Tabel 2. Kriteria Pengambilan Sampel

\begin{tabular}{|c|c|}
\hline Kriteria & Jumlah \\
\hline $\begin{array}{l}\text { Perbankan yang terdaftar di Bursa Efek Indonesia periode } \\
2016-2019\end{array}$ & 45 \\
\hline $\begin{array}{l}\text { Perbankan yang tidak melaporkan Laporan Keuangan dan } \\
\text { Annual Report secara konsisten di Bursa Efek Indonesia } \\
\text { periode } 2016 \text { - } 2019\end{array}$ & (18) \\
\hline $\begin{array}{l}\text { Perbankan yang tidak mengalami Financial Distress dan } \\
\text { Non Financial Distress berturut - turut selama periode } \\
2016 \text { - } 2019\end{array}$ & (6) \\
\hline Total Sampel & 21 \\
\hline - $\quad$ Financial Distress & 6 \\
\hline - $\quad$ Non Financial Distress & 15 \\
\hline $\begin{array}{l}\text { Total Sampel yang digunakan sesuai periode penelitian ( } 21 \\
\mathrm{x} 4)\end{array}$ & 84 \\
\hline
\end{tabular}

Pada tabel 2 menunjukkan bahwa berdasarkan kriteria Purposive Sampling perbankan yang terdaftar di Bursa Efek Indonesia adalah 45 perbankan. Perbankan diseleksi sesuai dengan kriteria yang sudah ditetapkan. Hasil seleksi sampel penelitian yaitu sebanyak 21 perbankan, perbankan yang mengalami Financial Distress selama periode 2016 - 2019 sebanyak 6 perbankan serta perbankan yang tidak pernah mengalami Financial Distress selama periode 2016 - 2019 sebanyak 15 perbankan.

Dalam penelitian ini menggunakan Regresi logistik untuk mengetahui pengaruh variabel independen terhadap variabel dependen. Logistic regression digunakan untuk menguji apakah probabilitas terjadinya variabel dependen dapat diprediksi dengan variabel independennya (Ghozali, 2013:333) Untuk pengujian regresi logistik menggunakan rumus sebagai berikut:

$$
\text { Logit FINC_DIS }=\boldsymbol{\beta} 0+\boldsymbol{\beta} 1 \mathrm{NPL}+\boldsymbol{\beta} 2 \mathrm{LDR}+\boldsymbol{\beta} 3 \mathrm{GCG}+\boldsymbol{\beta} 4 \mathrm{ROA}+\boldsymbol{\beta} 5 \mathrm{CAR}+\boldsymbol{\varepsilon}
$$

Keterangan :

FINC_DIS = variabel dummy untuk kemungkinan financial distress, yaitu: nilai 1 (satu) untuk perusahaan financial distress dan nilai 0 (nol) untuk perusahaan non financial distress.

$\beta 0=$ Konstanta

$\beta 1-5=$ Koefisien

NPL $=$ Non Performing Loan 
Owner: Riset \& Jurnal Akuntansi

e-ISSN : 2548-9224 |p-ISSN : 2548-7507

Volume 5 Nomor 1, Februari 2021

$\mathrm{LDR}=$ Loan to Deposits

GCG $=$ Good Corporate Covernance

$\mathrm{CAR}=$ Capital Adequacy

ROA $=$ Return on Assets

$\varepsilon=$ Error

\section{Menilai kelayakan model regresi}

\section{HASIL}

Hasil dari kelayakan regresi dinilai dengan goodness of fit yang diukur dengan Chi-Square pada bagian bawah uji Hosmer and Lemeshow dengan ketentuan jika nilai signifikansi dalam Hosmer and Lemeshow > 0,05 maka model yang digunakan dalam penelitian dikatakan fit dan layak untuk digunakan dalam analisis selanjutnya.

Tabel 3. Hasil Uji Hosmer and Lemeshowis

Hosmer and Lemeshow Test

\begin{tabular}{cc|c|c} 
Step & Chi-square & df & Sig. \\
\hline 1 & 12,308 & 8 &, 138 \\
\hline
\end{tabular}

Sumber: Data diolah penulis dari SPSS 25, 2020

Dari output di atas terlihat bahwa nilai Chi Square adalah sebesar 12,308 dengan nilai sig sebesar 0.138. Dari hasil tersebut terlihat bahwa nilai sig lebih besar daripada 0.05 sehingga model regresi layak untuk digunakan dalam analisis selanjunya, karena tidak ada perbedaan yang nyata antara klasifikasi yang diprediksi dengan klasifikasi yang diamati. Atau dapat dikatakan bahwa model mampu memprediksi nilai observasinya.

\section{Menilai Keseluruhan Model (Overall Model Fit)}

Untuk menilai keseluruhan model (overall fit model) ditunjukkan dengan nilai -2 Log Likehood dimana jika nilai -2 Log Likehood (block Number $=0$ ) lebih besar dibandingkan dengan nilai -2 Log Likehood (block Number=1), maka keseluruhan model menunjukkan model regresi yang baik. Jika terjadi penurunan, maka model tersebut menunjukkan model regresi yang baik. Hasilnya dapat di lihat pada tabel berikut :

Tabel 4. Hasil Uji Overall Model Fit

\section{Iteration History ${ }^{\mathrm{a}, \mathrm{b}, \mathrm{c}}$}

\begin{tabular}{lrr|r}
\multicolumn{2}{c}{} & \multicolumn{1}{c|}{$\begin{array}{c}-2 \text { Log } \\
\text { likelihood }\end{array}$} & \multicolumn{2}{c}{$\begin{array}{c}\text { Coefficients } \\
\text { Constant }\end{array}$} \\
\hline Steration 0 & 1 & 100,570 &,- 857 \\
\cline { 2 - 4 } & 2 & 100,509 &,- 916 \\
\hline \multirow{2yyy}{3}{3} & 100,509 &,- 916 \\
\hline
\end{tabular}

Sumber: Data diolah penulis dengan SPSS 25, 2020.

\begin{tabular}{|c|c|c|c|c|c|c|c|c|}
\hline \multicolumn{9}{|c|}{ Iteration History ${ }^{\mathrm{a}, \mathrm{b}, \mathrm{c}, \mathrm{d}}$} \\
\hline \multirow{2}{*}{\multicolumn{2}{|c|}{ Iteration }} & $-2 \log$ & \multicolumn{6}{|c|}{ Coefficients } \\
\hline & & $\begin{array}{c}\text { likelihoo } \\
\text { d }\end{array}$ & $\begin{array}{c}\text { Const } \\
\text { ant }\end{array}$ & NPL & LDR & GCG & ROA & CAR \\
\hline \multirow[t]{6}{*}{ Step 1} & 1 & 70,034 &,- 069 & , 101 &,- 025 & ,676 &,- 252 &,- 002 \\
\hline & 2 & 64,790 &,- 215 & , 163 &,- 036 & 1,026 &,- 409 &, 000 \\
\hline & 3 & 64,231 &,- 196 & , 187 &,- 040 & 1,155 &,- 497 &, 000 \\
\hline & 4 & 64,218 &,- 160 &, 189 &,- 040 & 1,168 &,- 517 &, 000 \\
\hline & 5 & 64,218 &,- 158 & , 190 &,- 040 & 1,168 &,- 517 & 000 \\
\hline & 6 & 64,218 &,- 158 & , 190 &,- 040 & 1,168 &,- 517 & ,000 \\
\hline
\end{tabular}


Owner: Riset \& Jurnal Akuntansi

e-ISSN : 2548-9224|p-ISSN : 2548-7507

Volume 5 Nomor 1, Februari 2021

DOI : https://doi.org/10.33395/owner.v5i1.320

Sumber: Data diolah penulis dengan SPSS 25, 2020.

Dari output di atas terlihat bahwa nilai -2 Log Likehood (block Number=0) sebesar 100,509 dan pada nilai -2 Log Likehood (block Number=1) sebesar 64,218. Hasil tersebut dapat menunjukkan model regresi logistik yang baik karena, nilai-2 Log Likehood (block Number=0) lebih besar dibandingkan dengan nilai -2 Log Likehood (block Number=1).

\section{Regresi Logistik}

Uji regresi logistik dilakukan untuk mengetahui besarnya pengaruh hubungan variabel independen terhadap variabel dependen. Besarnya pengaruh variabel independen terhadap variabel dependen secara bersama-sama dapat dihitung melalui suatu persamaan regresi logistik. Hasil uji regresi logistik dapat dilihat dari tabel berikut:

Tabel 5. Hasil Uji Regresi Logistik

\begin{tabular}{|c|c|c|c|c|c|c|c|c|c|}
\hline \multicolumn{10}{|c|}{ Variables in the Equation } \\
\hline & & \multirow[b]{2}{*}{ B } & \multirow[b]{2}{*}{ S.E. } & \multirow[b]{2}{*}{ Wald } & \multirow[b]{2}{*}{ df } & \multirow[b]{2}{*}{ Sig. } & \multirow[b]{2}{*}{$\operatorname{Exp}(B)$} & \multicolumn{2}{|c|}{$\begin{array}{c}\text { 95\% C.I.for } \\
\text { EXP(B) }\end{array}$} \\
\hline & & & & & & & & Lower & Upper \\
\hline \multirow[t]{6}{*}{ Step $1^{\mathrm{a}}$} & NPL & ,190 & ,217 & ,763 & 1 & ,383 & 1,209 & ,790 & 1,849 \\
\hline & LDR &,- 040 & 025 & 2,544 & 1 & 111 & ,961 & ,914 & 1,009 \\
\hline & GCG & 1,168 & ,733 & 2,538 & 1 & 111 & 3,216 & ,764 & 13,535 \\
\hline & ROA &,- 517 & 242 & 4,554 & 1 & 033 &, 596 & ,371 & ,959 \\
\hline & CAR &, 000 & 042 &, 000 & 1 & ,992 & 1,000 & ,921 & 1,085 \\
\hline & Constant &,- 158 & 3,043 & ,003 & 1 & 959 & ,854 & & \\
\hline
\end{tabular}

a. Variable(s) entered on step 1: NPL, LDR, GCG, ROA, CAR.

Sumber: Data diolah penulis dengan SPSS 25, 2020.

Dari hasil analisis dengan bantuan program SPSS 25, maka dapat diketahui persamaan regresi yang terbentuk. Adapun persamaan regresi logistik, sebagai berikut:

\section{Logit FINC_DIS $=-0,158+0,190 N P L-0,040 L D R+1,168 G C G-0,517 R O A+0,00 C A R+\varepsilon$}

Konstanta sebesar -0,158 menunjukkan bahwa jika variabel-variabel independen (NPL, LDR, GCG, ROA dan CAR) diasumsikan tidak mengalami perubahan (konstan) maka peluang perusahaan mengalami kondisi financial distress sebesar $-0,158 \%$.

\section{Uji Hipotesis}

Uji Wald

Pengujian dalam penelitian ini dilakukan untuk mengetahui hubungan variabel-variabel independen. Pengujian dilakukan menggunakan nilai signifikansi 5\% atau 0.05 karena dianggap cukup memadai dalam pembandingan antar variabel-variabel pengambilan keputusan berdasarkan probabilitas.

Tabel 6. Hasil Uji Wald

\begin{tabular}{|c|c|c|c|c|c|c|c|c|c|}
\hline \multicolumn{10}{|c|}{ Variables in the Equation } \\
\hline & & \multirow[b]{2}{*}{ B } & \multirow[b]{2}{*}{ S.E. } & \multirow[b]{2}{*}{ Wald } & \multirow[b]{2}{*}{ df } & \multirow[b]{2}{*}{ Sig. } & \multirow{2}{*}{$\begin{array}{c}\operatorname{Exp}( \\
B)\end{array}$} & \multicolumn{2}{|c|}{$\begin{array}{c}95 \% \text { C.I.for } \\
\text { EXP(B) }\end{array}$} \\
\hline & & & & & & & & Lower & Upper \\
\hline \multirow[t]{4}{*}{ Step $1^{\mathrm{a}}$} & NPL & ,190 & ,217 & ,763 & 1 & ,383 & 1,209 & ,790 & 1,849 \\
\hline & LDR &,- 040 & ,025 & 2,544 & 1 & ,111 & ,961 & 914, & 1,009 \\
\hline & GCG & 1,168 &, 733 & 2,538 & 1 &, 111 & 3,216 & ,764 & 13,535 \\
\hline & ROA &,- 517 & 242 & 4,554 & 1 & 033, & 596, & 371 & 959, \\
\hline
\end{tabular}




\begin{tabular}{l|r|r|r|r|r|r|r|r}
\hline CAR &, 000 &, 042 &, 000 & 1 &, 992 & 1,000 &, 921 & 1,085 \\
\hline Constant &,- 158 & 3,04 &, 003 & 1 &, 959 &, 854 & & \\
& & 3 & & & & & & \\
\hline
\end{tabular}

a. Variable(s) entered on step 1: NPL, LDR, GCG, ROA, CAR.

Sumber: Data diolah penulis dengan SPSS 25, 2020.

Berdasarkan tabel diatas dapat diambil kesimpulan bahwa :

Dari tabel di atas dapat dilihat nilai beta sebesar 0,190 dengan signifikansi 0,383. Karena memiliki nilai signifikansi di atas 0,05 menunjukkan bahwa variabel risk profile yang diukur dengan Non Performing Loan (NPL) tidak berpengaruh terhadap financial distress.

Dari tabel di atas dapat dilihat nilai beta sebesar -0,040 dengan signifikansi 0,111. Karena memiliki nilai signifikansi di atas 0,05 menunjukkan bahwa variabel risk profile yang diukur dengan Loan to Deposit Ratio (LDR) tidak berpengaruh terhadap financial distress.

Dari tabel di atas dapat dilihat nilai beta sebesar 1,168 dengan signifikansi 0,111. Karena memiliki nilai signifikansi di atas 0,05 menunjukkan bahwa variabel Good Corporate Governance (GCG) yang di ukur dengan nilai komposit tidak berpengaruh terhadap financial distress.

Dari tabel di atas dapat dilihat nilai beta sebesar $-0,517$ dengan signifikansi 0,033. Karena memiliki nilai signifikansi di bawah 0,05 dan memiliki nilai beta negatif menunjukkan bahwa variabel earning yang diukur dengan Return on Asset (ROA) memiliki pengaruh negatif terhadap financial distress.

Dari tabel di atas dapat dilihat nilai beta sebesar 0,00 dengan signifikansi 0,992. Karena memiliki nilai signifikansi di atas 0,05 menunjukkan bahwa variabel capital yang diukur dengan Capital Adequacy Ratio (CAR) tidak berpengaruh terhadap financial distress.

\section{Uji Omnibus Test}

Pengaruh RGEC terhadap financial distress dapat dilihat dari tabel omnibus test of model coefficients (pengujian simultan), dengan ketentuan adalah jika nilai signifikansi lebih kecil dari 0,05 maka hipotesis dapat diterima.

Tabel 7. Hasil Uji Omnibus Test

\section{Omnibus Tests of Model Coefficients}

\begin{tabular}{ll|r|r|r} 
& & Chi-square & df & \multicolumn{1}{c}{ Sig. } \\
\hline Step 1 & Step & 36,292 & 5 &, 000 \\
& & & & \\
\cline { 2 - 5 } & Block & 36,292 & 5 &, 000 \\
\hline & Model & 36,292 & 5 &, 000 \\
\hline
\end{tabular}

Sumber : Data diolah penulis dengan SPSS 25, 2020.

Berdasarkan tabel 4.13 dapat dilihat bahwa nilai Chi-square adalah sebesar 36,292 dan degree of freedom sebesar 5, serta signifikansi sebesar 0,000. Hal ini berarti bahwa $(0,000<0,05)$ dengan demikian, kondisi ini berarti bahwa variabel independen yaitu NPL, LDR, GCG, ROA dan CAR secara bersama-sama memiliki pengaruh untuk memprediksi kondisi financial distress pada bank yang terdaftar di Bursa Efek Indonesia periode 2016-2019.

\section{Koefisien Determinasi}

Nagelkerke $R$ Square merupakan modifikasi dari koefisien Cox \& Snell yang merupakan pengujian yang dilakukan untuk mengetahui seberapa besar variabel independen mampu menjelaskan dan mempengaruhi variabel dependen. 


\begin{tabular}{lr|r|r} 
Step & $\begin{array}{c}-2 \text { Log } \\
\text { likelihood }\end{array}$ & $\begin{array}{c}\text { Cox \& Snell R } \\
\text { Square }\end{array}$ & \multicolumn{2}{|c}{$\begin{array}{c}\text { Nagelkerke R } \\
\text { Square }\end{array}$} \\
\hline 1 & $64,218^{\mathrm{a}}$ &, 351 &, 503 \\
\hline
\end{tabular}

a. Estimation terminated at iteration number 6 because parameter estimates changed by less than, 001 .

Sumber: Data diolah penulis dengan SPSS 25, 2020.

Besarnya koefisien regresi dapat dilihat dalam kolom Cox \& Snell R Square dan Nagelkerke $R$ Square. Berdasarkan hasil pengolahan data dengan menggunakan metode regresi logistik, maka didapat koefisien determinasi yang dilihat dari Cox \& Snell $R$ Square sebesar 0,351 atau 35,1\% dan Nagelkerke $R$ Square sebesar 0,503 atau 50,3\%. Hal ini menunjukkan kombinasi variabel independen yaitu rasio NPL, LDR, GCG, ROA dan CAR mampu menjelaskan variasi dari variabel dependen yaitu financial distress yaitu sebesar 50,3\% sedangkan sisanya 49,7\% oleh faktor lain yang tidak diikutsertakan dalam model.

\section{PEMBAHASAN}

\section{Pengaruh Non Performing Loan (NPL) Secara Parsial Terhadap Financial Distress}

Non Performing Loan secara parsial tidak berpengaruh terhadap financial distress pada perbankan yang terdaftar di Bursa Efek Indonesia periode 2016-2019. Dengan diperoleh nilai beta sebesar 0,190 dengan signifikansi 0,383, Hal ini menunjukkan bahwa semakin tinggi nilai Non Performing Loan tidak dapat mempengaruhi Financial distress. Hasil temuan ini mendukung hasil penelitian terdahulu yang dilakukan oleh Zahronya dan Mahardika (2018) bahwa NPL tidak berpengaruh signifikan terhadap Financial Distress.

\section{Pengaruh Loan to Deposit Ratio (LDR) Secara Parsial Terhadap Financial Distress}

Loan to Deposit Ratio secara parsial tidak berpengaruh terhadap financial distress pada perbankan yang terdaftar di Bursa Efek Indonesia periode 2016-2019. Dengan diperoleh nilai beta sebesar -0,040 dengan signifikansi 0,111, Hal ini menunjukkan bahwa semakin tinggi nilai Loan to Deposit Ratio tidak dapat mempengaruhi Financial distress. Hasil temuan ini mendukung hasil penelitian terdahulu yang dilakukan oleh Sofiasani dan Gautama (2016) bahwa LDR tidak berpengaruh terhadap Financial Distress.

\section{Pengaruh Good Corporate Governance (GCG) Secara Parsial Terhadap Financial Distress}

Good Gorporate Governance secara parsial tidak berpengaruh terhadap financial distress pada perbankan yang terdaftar di Bursa Efek Indonesia periode 2016-2019. Dengan diperoleh nilai beta sebesar 1,168 dengan signifikansi 0,111, Hal ini menunjukkan bahwa semakin tinggi/rendah nilai Good Corporate Governance tidak dapat mempengaruhi Financial distress. Hasil temuan ini mendukung hasil penelitian terdahulu yang dilakukan oleh Sadida (2018) bahwa GCG tidak berpengaruh terhadap Financial Distress.

\section{Pengaruh Return on Assets (ROA) Secara Parsial Terhadap Financial Distress}

Return on Asset secara parsial berpengaruh negatif terhadap financial distress pada perbankan yang terdaftar di Bursa Efek Indonesia periode 2016-2019. Dengan diperoleh nilai beta sebesar -0,517 dengan signifikansi 0,033. Hal ini menunjukkan bahwa semakin tinggi nilai Return on Asset (ROA) dapat membuat perbankan tidak mengalami Financial distress dan apabila nilai ROA menurun dapat membuat perbankan mengalami Financial Distress. Hasil temuan ini mendukung hasil penelitian terdahulu yang dilakukan oleh Andari dan Wiksuana (2017) bahwa ROA berpengaruh negatif terhadap Financial Distress.

\section{Pengaruh Capital Adequacy Ratio (CAR) Secara Parsial Terhadap Financial Distress}

Capital Adequacy Ratio secara parsial tidak berpengaruh terhadap financial distress pada perbankan yang terdaftar di Bursa Efek Indonesia periode 2016-2019. Dengan diperoleh nilai beta sebesar 0,00 dengan signifikansi 0,992, Hal ini menunjukkan bahwa semakin tinggi/rendah nilai 
Capital Adequacy Ratio tidak dapat mempengaruhi Financial distress. Hasil temuan ini mendukung hasil penelitian terdahulu yang dilakukan oleh Wijaya, Wahjoe dan Kurnia (2018) bahwa CAR tidak berpengaruh terhadap Financial Distress.

\section{Pengaruh NPL, LDR, GCG, ROA dan CAR Secara Simultan Terhadap Financial Distress}

Berdasarkan hasil pengujian dapat dilihat bahwa nilai signifikansi sebesar 0,000. Dengan demikian, dapat disimpulkan bahwa variabel NPL, LDR, GCG, ROA dan CAR secara bersamaan berpengaruh signifikan terhadap Financial Distress pada perbankan yang terdaftar di Bursa Efek Indonesia periode 2016-2019. Dan hasil penelitian ini terlihat bahwa pengaruh dari kelima variabel independen yaitu NPL, LDR, GCG, ROA dan CAR dapat merubah kondisi Financial Distress pada perbankan. Kondisi Financial Distress dan Non Financial Distress bergantung pada tinggi atau rendahnya nilai NPL, LDR, GCG, ROA dan CAR.

\section{KESIMPULAN}

Berdasarkan hasil analisis regresi logistik, dapat diungkapkan bahwa Return on Asset berpengaruh negatif terhadap Financial Distress. Sedangkan Non Performing Loan, Loan to Deposit Ratio, Good Corporate Governance, dan Capital Adequacy Ratio tidak memiliki pengaruh terhadap Financial Distress. Secara simultan Non Performing Loan, Loan to Deposit Ratio, Good Corporate Governance, Return on Asset, Capital Adequacy Ratio berpengaruh terhadap Financial Distress.

\section{Saran}

Bagi pihak perbankan diharapkan lebih memperhatikan serta meningkatkan nilai Return on Asset perbankan dengan cara menurunkan biaya dana dan meningkatkan realisasi kredit berkualitas serta mengelola perbankan dengan tepat karena, semakin tinggi Return on Asset akan semakin kecil perbankan mengalami Financial Distress. Untuk peneliti selanjutnya, penulis menyarankan dapat menggunakan indikator eksternal lainnya agar dapat memperoleh hasil yang lebih bervariatif, misal inflasi, kurs dan sebagainya. Penulis juga menyarankan agar menggunakan metode penelitian logistik multinominal.

\section{REFERENSI}

Andari, N. M., \& Wiksuana, I. (2017). Rgec Sebagai Determinasi Dalam Menaggulangi Financial Distress Pada Perusahaan Perbankan Di Bursa Efek Indonesia. E-Jurnal Manajemen Unud, Vol.6, No.1, 116-145.

Bhattacharjee, A., \& Han, J. (2014). Financial Distress of Chinese Firm: Microeconomic, Macroeconomic and Institutional Influences. China Economic Review Volume 30, 244262.

Diena, B. (2018). Risk Profile, Good Corporate Governance, Earning and Capital (RGEC) Sebagai Prediktor Terhadap Kondisi Financial Distress Pada Perusahaan Perbankan. Jurnal Manajemen Bisnis Indonesia Edisi 4.

Ghozali, I. (2016). Aplikasi Analisis Multivariate dengan Program IBM SPSS 23. Semarang: Universitas Diponegoro.

Hamdani. (2016). Good Corporate Governance Tinjauan Etika dalam Praktik Bisnis. Jakarta: Mitra Wacana Media.

Ismail. (2014). Akuntansi Bank: Teori dan Aplikasi dalam Rupiah Edisi Revisi. Jakarta: Kencana. Kasmir. (2013). Bank dan Lembaga Keuangan Lainnya. Jakarta: Rajawali Pers.

Kasmir. (2014). Analisis Laporan Keuangan, Edisi Pertama, Cetakan Ketujuh. Jakarta: PT. Rajagrafindo Persada.

Khadapi, M. (2017). Pengaruh Car, Roa, Bopo dan Fdr Terhadap Financial Distress Bank Umum Syariah di Indonesia Periode 2014-2016. Skripsi.

Prabowo, D., \& Purwanto, A. (2015). Analisis Faktor-faktor yang mempengaruhi intellectual capital disclosure dan pengaruh intellectual capital disclosure terhadap market capitalization. Diponegoro Journal of Accounting. 
Riyadi, S. (2011). Banking Assets and Liability Management. Jakarta: Fakultas Ekonomi Universitas Indonesia.

Riyadi, S. (2015). Banking Asset and Liability Management, Edisi keempat. Jakarta: Fakultas Ekonomi Universitas Indonesia.

Ruslinawati, H. A. (2017). Pengaruh Rasio Keuangan Terhadap Financial Distress pada Perusahaan Manufaktur yang Listing di BEI 2011-2015. Skripsi.

Rustandi, F. (2019). Pengaruh Rgec (Risk Profile, Good Corporate Governance, Earnings, Capital) Terhadap Financial Distress Bank Perkreditan Rakyat di Yogyakarta Periode 2015-2017. Jurnal.

Sagho, M. F., \& Merkusiwati, N. (2015). Penggunaan Metode Altman Z-Score Modifikasi Untuk Memprediksi Kebangkrutan Bank yang Terdaftar di Bursa Efek Indonesia. E-Jurnal Akuntansi Universitas Udayana 11.3, 730-742.

Sajuri, A. S. (2018). Analisis Pengaruh Rasio Camel Terhadap Prediksi Financial Distress pada Perbankan yang Terdaftar di BEI tahun 2012-2016. Skripsi.

Scott, W. R. (2012). Financing Accounting Theory 6th. Toronto: Pearson Education Canada.

Septiwardani, D. (2018). Pengaruh Likuiditas dan Ukuran Perusahaan Terhadap Financial Distress. Skripsi.

Sofiasani, G., \& Gautama, B. (2016). Pengaruh Camel Terhadap Financial Distress pada Sektor Perbankan Indonesia Periode 2009-2013. Journal of Business Management and Enterpreneurship Education Vol 1 Number 1, 136-146.

Suwardjono. (2013). Teori Akuntansi Perekayasaan Pelaporan Keuangan. Yogjakarta: BPFE.

Theodorus, S., \& Artini, L. (2018). Studi Financial Distress Pada Perusahaan Perbankan di BEI. EJurnal Manajemen Unud, Vol 7, No.5, 2710-2732.

Wijaya, R. R., Hapsari, D., \& Kurnia. (2018). Pengaruh Rasio Camel Terhadap Financial Distress pada Bank Umum Syariah di Indonesia Periode 2011-2015. E-Proceeding of Management :Vol.5, No.1, 786.

Zahronyana, B. D., \& Mahardika, D. (2018). Assessing Probabilities of Financial Distress of Banks in UAE. International Journal of Managerial Finance, 90-98. 